\title{
EVALUASI PROGRAM PENDIDIKAN KARAKTER DI SEKOLAH DASAR ISLAM DAARUS SHOFWAH BOJONGGEDE - BOGOR
}

\section{Nurul Faujiah | Santosa Muwarni | Elin Driana}

How to cite : Faujiah, Nurul., Muwarni, Santosa., \& Driana, Elin., 2021. EVALUASI PROGRAM PENDIDIKAN KARAKTER DI SEKOLAH DASAR ISLAM DAARUS SHOFWAH BOJONGGEDE - BOGOR. Jurnal Penelitian dan Penilaian Pendidikan. 3(2). 200 $-211$.

To link to this article : https://doi.org/10.22236/jppp.v3i1.7305

(C)2021. The Author(s). This open access article is distributed under a Creative Commons Attribution (CC BY-SA) 4.0 license.

\section{MI \\ Published Online on 30 July 2021}

\section{4 https://journal.uhamka.ac.id/index.php/jppp}

View Crossmark data $\longleftarrow$ 
EVALUASI PROGRAM PENDIDIKAN KARAKTER DI SEKOLAH DASAR ISLAM DAARUS SHOFWAH BOJONGGEDE - BOGOR

\author{
Nurul Faujiah $^{1}$, Santosa Muwarni $^{2}$, Elin Driana ${ }^{3}$ \\ 1,2,3 Universitas Muhammadiyah Prof. Dr. HAMKA \\ E-mail: $\quad$ Nurul.fauziyah@uhamka.ac.id ${ }^{1)}$ \\ Santosa.muwarni@uhamka.ac.id22) \\ elin@uhamka.ac.id ${ }^{3)}$
}

Received : 15 April 2021

Accepted: 25 July 2021

Published Online: 30 July 2021

\begin{abstract}
Abstrak
Penelitian ini bertujuan untuk mendeskripsikan dan mengevaluasi ketercapaian program pendidikan karakter di SD Islam Daarus Shofwah Bojonggede Bogor. Jenis penelitian ini adalah evaluasi melalui metode pendekatan kualitatif dengan menggunakan model CIPP (Context, Input, Process, dan Product) sebagai alat evaluasi. Pengumpulan data pada proses evaluasi yaitu observasi, wawancara, dan studi dokumentasi. Wawancara dilakukan dengan kepala sekolah, wakil bidang kurikulum, wakil bidang kesiswaan, guru kelas, guru PAI, guru olahraga, perwakilan guru ekstrakulikuler, perwakilan siswa kelas 5 dan 6 . Hasil penelitian ini dapat disimpulkan bahwa program pendidikan karakter dikategorikan baik. Sedangkan pada nilai evaluasi program pendidikan karakter berdasarkan masing-masing tahapan diantaranya pada tahapan konteks (Context) berada pada kategori baik, pada tahapan masukan (Input) berada pada kategori baik, pada thapan proses (Process) berada pada kategori sangat baik, dan tahapan produk (Product) pada kategori baik.
\end{abstract}

Kata Kunci : CIPP, Evaluasi program, Pendidikan Karakter, SD Islam Daarus Shofwah.

\begin{abstract}
This study aims to describe and evaluate the achievement of the character education program at SD Islam Daarus Shofwah Bojonggede Bogor. This type of research is an evaluation through a qualitative approach using the CIPP model (Context, Input, Process, and Product) as an evaluation tool. Collecting data in the evaluation process, namely observation, interviews, and documentation studies. Interviews were conducted with school principals, curriculum representatives, student representatives, class teachers, PAI teachers, sports teachers, extracurricular teacher representatives, grade 5 and 6 student representatives. The results of this study can be concluded that the character education program is categorized as good. Whereas the evaluation value of the character education program based on each stage includes the context stage which is in the good category, the input stage which is in the good category, the process stage which is in the very good category, and the product stage. (Product) in the good category.
\end{abstract}

Keywords: CIPP, Program Evaluation, Character Education, Daarus Shofwah Islamic Elementary School.

This is an open access article under the Creative Commons Attribution 4.0 International License 
Evaluasi Program Pendidikan Karakter...

\section{PENDAHULUAN}

Pendidikan karakter adalah suatu sistem pendidikan yang bertujuan untuk menanamkan nilai-nilai karakter tertentu kepada peserta didik. Nilai-nilai karakter, seperti kejujuran, kesantunan, kebersamaan, dan religius sedikit demi sedikit mulai tergeser oleh budaya asing, sehingga nilai-nilai karakter tersebut tidak lagi dianggap penting jika bertentangan dengan tujuan yang diperoleh. Hermino (2016) mengatakan karakter seseorang dipengaruhi oleh faktor lingkungan dan faktor bawaan. Karakter melekat pada setiap individu, yang tercermin pada perilaku kehidupan sehari-hari. Pendidikan karakter bukan hanya berurusan dengan penanaman nilai bagi peserta didik, namun merupakan suatu usaha bersama untuk menciptakan lingkungan pendidikan sebagai kehidupan yang bermoral. Menilai berhasil tidaknya pendidikan karakter dalam sebuah lembaga pendidikan memang tidak semudah menilai kemampuan akademis siswa. Dalam pendidikan karakter yang dinilai bukan pemahaman, tetapi perilaku.

Pemerintah resmi menerbitkan peraturan presiden (Perpes) No 87 Tahun 2017 pasal 1 ayat 1 tentang penguatan pendidikan karakter yang berisikan Penguatan pendidikan karakter yang selanjutnya disingkat PPK adalah gerakan pendidikan di bawah tanggungjawab satuan pendidikan untuk memperkuat karakter peserta didik melalui harmonisasi olah hati, olah rasa, olah pikir, dan olah raga dengan pelibatan dan kerjasama antara satuan pendidikan, keluarga, dan masyarakat sebagai bagian dari Gerakan Nasional Revolusi Mental(GNRM).

Ditegaskan dalam perpres tersebut bahwasanya pendidikan karakter diselenggarakan di tiga satuan pendidikan yakni jalur formal, nonformal dan informal. Satuan pendidikan pada jalur pendidikan formal, pendidkan karakter formal terintegrasi dalam tiga kegiatan yakni intrakulikuler, kokurikuler, dan ekstrakulikuler.

Di lingkungan sekolah, karakter sangat penting untuk dibentuk, terutama pada masa anak-anak, karena pada masa ini anak masih labil dalam menentukan mana yang positif dan mana yang negatif, hal demikian membuat anak bertindak sesuai dengan keinginan hatinya. Jika siswa tidak mempunyai karakter, dia akan mudah terjerumus ke dalam suatu perbuatan yang negatif. Dengan dibentuknya pendidikan karakter, anak mempunyai benteng untuk menjaga diri dalam bertindak dan berbuat dalam kehidupan sehari-hari. Jika siswa tidak mempunyai karakter yang baik, maka besar kemungkinan anak didik akan terjerumus ke dalam suatu hal yang negatif.

Seperti kasus pada bulan Maret 2019 dikutip dari Maxmanroe (2019), seorang siswa laki-laki kelas 2 sekolah dasar di daerah Bogor Jawa Barat, melakukan perbuatan yang sepatutnya tidak ia lakukan. Siswa tersebut melakukan perbuatan asusila kepada temannya yang sesama jenis. Ia melakukannya hal tersebut ketika di kamar mandi pada waktu istirahat. Setelah ditelurusi siswa tersebut mengaku sering melihat kakaknya melakukan serupa ketika di rumah. Setiap hari siswa tersebut dititipkan kepada asisten rumah tangganya. Siswa tersebut sering diberikan tontonan-tontonan yang tidak layak untuk ditonton untuk siswa seusianya oleh asisten rumah tagganya tersebut. Kurangnya perhatian dari kedua orang tuanya menyebabkan anak melakukan hal tersebut, karena orang tua siswa tersebut semuanya pekerja, yang setip harinya berangkat di pagi hari dan pulang larut malam.

Vol. 3 No. 2 (2021) 
Pada kasus lainnya dikutip dari liputan6 (2019) seorang siswi kelas empat SD di Probolinggo, Jawa Timur, menjadi korban kekerasan seksual yang dilakukan dua teman sekelasnya. Pelaku bahkan sempat mengancam korban saat menjalankan aksi kejinya di dalam ruang kelas. Di hadapan sejumlah temannya, pelaku yang salah satunya pernah tinggal kelas selama dua kali memaksa bahkan mengancam korban dengan sebilah pisaucutter.

Melihat permasalahan tersebut di atas, pendidikan karakter menjadi penting di era modernisasi saat ini. Permasalaha tersebut di atas seperti itulah yang perlu dicari solusinya. Pembentukan karakter sejak dini menjadi solusi awal dari permasalahan di atas. Hal tersebut tentunya memerlukan adanya kesadaran dari semua pihak-pihak yang berinteraksi langsung, seperti orang tua, guru, dan masyarakat sekitar lingkungannya untuk menciptakan generasi yang berkarakter.

Untuk membentuk karakter pribadi yang matang diperlukan proses yang terusmenerus dan berkesinambungan sepanjang kehidupan. Proses ini harus dimulai sejak dini karena pada tahap perkembangan individu, usia anak adalah saat yang tepat untuk menanamkan nilai-nilai karakter karena ini akan membentuk fondasi dasar untuk perkembangan selanjutnya. Pelaksanaan pendidikan karakter dalam proses belajar mengajar perlu dirancang sedemikian rupa, mulai dari perencanaan, pelaksanaan, dan Evaluasi. Seorang guru dalam merencanakan pembelajaran diminta untuk memperhatikan nilai-nilai karakter yang akan dicapai. Dalam pelaksanaan pembelajaran, guru dapat mencapai tujuan pembelajaran melalui strategi, metode, model, media maupun alat peraga. Selanjutnya, pada proses evaluasi pembelajaran, guru diminta menilai ketercapaian pendidikan karakter peserta didik yang terintegrasi dalam pembelajaran.

Seorang guru perlu mengajarkan pendidikan karakter kepada peserta didik di sekolah. Guru merupakan figur manusia yang mempunyai tugas dan tanggungjawab dalam hal mengajar, mendidik, membimbing, mengevaluasi dan melatih peserta didik dalam upaya menciptakan peserta didik yang memiliki pengetahuan, keterampilan, dan sikap yang menjadi bekal hidupnya di kemudian hari sebab guru merupakan komponen pendidikan.

Sebagai bangsa yang dikenal dengan budaya ketimuran yang memiliki karakteristik dalam tatanan kehidupan, bangsa kita perlu mempertahankan diri dari proses degradasi karakter bangsa yang mulai luntur ini. Penanaman karakter ini secara sistematis bisa dilakukan salah satunya melalui penambahan muatan dalam kurikulum sekolah. Sekolah adalah konteks sosial di mana anak belajar dan berinteraksi dengan lingkungannya. Dalam pendidikan karakter, sekolah menjadi komponen penting yang sangat berpengaruh terhadap keberhasilan program ini. Lingkungan sekolah memiliki peran penting dalam pembentukan karakter peserta didiknya. Karakter peserta didik dapat dibentuk dan dibina melalui pendidikan. Dengan demikian, pendidikan karakter merupakan sebuah usaha bersama dari seluruh komponen sekolah untuk menciptakan peserta didik yang berkarakter. 
Evaluasi Program Pendidikan Karakter...

\section{METODE}

Evaluasi dilakukan untuk memperoleh data secara lengkap, mendalam, dan berkesinambungan. Data yang diperoleh merupakan data yang berasal dari serangkaian proses, sehingga metode yang digunakan dalam evaluasi ini adalah metode kualitatif. Metode kualitatif dipercaya dapat membantu evaluator dalam merecord segala aktivitas atau tindakan yang dilakukan subjek berkaitan dengan objek yang dievaluasi.

Sesuai dengan permasalahan yang dievaluasi yaitu program pendidikan karakter, model evaluasi yang digunakan evaluator adalah evaluasi model CIPP. Evaluasi model CIPP digunakan karena sesuai dengan tujuan evaluasi untuk melihat konteksi, masukan, proses, dan hasil program pendidikan karakter yang ada di SD Islam Daarus Shofwah.

Untuk melaksanakan evaluasi dengan model CIPP, evaluator harus melakukan empat evaluasi yakni, evaluasi konteks, evaluasi input, evaluasi proses, dan evaluasi produk. Model ini dikembangkan oleh Stufflebeam pada tahun 1966 (Wirawan, 2016). Penelitian evaluatif model CIPP ini menilai dari keempat komponen yang saling berkaitan dan satu kesatuan yang utuh. Teknik dan prosedur pengumpulan data dalam penelitian ini adalah observasi, wawancara, dan studi dokumentasi.

\section{HASIL DAN PEMBAHASAN}

Tujuan dilakukannya evaluasi ini adalah untuk mendapatkan informasi secara mendalam tentang program pendidikan karakter yang dilaksanakan oleh guru dan sekolah, mencakup hal-hal yang menjadi aspek penting dalam evaluasi dengan model CIPP untuk selanjutnya diolah dan menghasilkan sebuah rekomendasi positif. Temuan evaluasi program pendidikan karakter di SD Islam Daarus Shofwah Bojonggede Bogor dilihat dari segi konteks, input, proses, dan produk adalah sebagai berikut :

Pertama, komponen konteks dalam evaluasi ini dibahas komponen-komponen yang menjadi dasar pelaksanaan program terhadap apa yang ingin dicapai. Visi dan Misi Sekolah merupakan bagian dari komponen konteks, karena melalui hal tersebut pihak sekolah menggambarkan strerategi dan rencana pencapaian yang diharapkan. Hasil evaluasi menjelaskan, bahwa Visi dan Misi SD Islam Daarus Shofwah Bojonggede, Bogor adalah hasil musyawarah tim yayasan dan pejabat yang terkait di SD Islam Daarus Shofwah, dimana visi dan misi sama dengan visi misi pesantren yang ada di lingkungan tersebut yang kemudian diberikan kepada mandat untuk bersama-sama melaksanakan apa yang menjadi tujuan yang terkadung dalam visi dan misi. Artinya berdasarkan hasil temuan tersebut, baik guru maupun siswa tidak dilibatkan dalamperumusan visi dan misi, namun ikut serta dalam mencapai tujuan yang terkandung dalam visi dan misi tersebut.

Kedua, input dalam penelitian ini merupakan daya pendukung yang menjamin keterlaksanaan suatu program. Dalam pelaksanaan program pendidikan karakter di SD Islam Daarus Shofwah Bojonggede, Bogor setidaknya ada 4 komponen yang menjadi perhatian penting evaluator dalam melakukan evaluasi terhadap pelaksanaan pendidikan karakter, yaitu: 1) Rencana pelaksanaan, 2) Anggaran 3) Sumberdaya manusia, 4)Sarana dan Prasaran, 5) Orang tua, dan 6) kurikukulum. 
1) Rencana Pelaksanaan, temuan hasil evaluasi melalui wawancara dengan narasumber, menjelaskan, bahwa dalam pelaksaan program pendidikan karakter di SD Islam Daarus Shofwah terdapat perencanaan khusus, karena diyakini program pendidikan karakter merupakan hal yang penting yang harus ada pada setiap manusia khusus peserta didik serta pendidikan karakter merupakan bagian yang tidak terpisah dari pelaksanaan kurikulum.

2) Anggaran, Dalam pelaksanaan program pendidikan karakter yang diimplementasikan melalui kegiatan intrakulikuler, kokulikuler dan ekstrakulikuler yang dilaksanakan sekolah, tentunya ada pembiayaan atau anggaran yang harus dikeluarkan sekolah demi tercapainya tujuan. Anggaran tersebut dikeluarkan untuk kegiatan-kegiatan maupun sarana prasarana dalam menunjang program pendidikan karakter. Temuan evaluator pada terkait alokasi anggaran dalam pelaksanaan program pendidikan karakter di SD Islam Daarus Shofwah adalah, bahwa dalam pelaksanaan program pendidikan karakter menyediakan alokasi angaran khusus.

3) Sumberdaya Manusia, temuan berikutnya terkait sumber daya manusia (SDM). SDM yang dimaksud adalah kepala sekolah, wali kelas, guru, dan peserta didik di SD Islam Daarus Shofwah Bojonggede Bogor. Hasil dari observasi dan wawancara dengan sumberdaya manusia yang berada di lingkungan sekolah tersebut, dapat disimpulkan bahwa kepala sekolah telah membuat perencanaan dan mensosialisasikan program pendidikan karakter kepada setiap guru melalui rapat dengan dewan guru, dan kemudian guru menyampaikan hal tersebut kepada peserta didik. Hasil pengamatan para pendidik pada umumnya menunjukkan sikap yang baik selama di sekolah. Satu-satunya hal negatif yang teramati adalah masalah kedisiplinan waktu yang buruk. Beberapa guru gagal menunjukkan contoh yang benar untuk selalu menghargai waktu. Kebiasaan guru datang terlambat akan membentuk kebiasaan serupa kepada siswa Peserta didik merupakan unsur yang penting dalam dunia pendidikan. Peserta didik menjadi faktor penentu berhasil atau tidaknya sekolah dalam memberikan kontribusi. Pada dasarnya, peserta didik membutuhkan pendekatan dari guruguru untuk mengetahui kendala yang dialami oleh sisiwa. Baik dalam proses pembelajaran ataupun yang lainnya, guru hendaknya memberikan solusi, sebagai penasehat dan motivator kepada peserta didik.

4) Sarana dan prasana, merupakan sebagai penunjang keberhasilan proses pendidikan di sekolah. Semakin lengkap dan memadai sarana dan prasarana yang dimiliki sekolah, semakin memudahkan guru dalam melaksanakan proses pembelajaran sebagai tenaga pendidik. Hasil observasi terhadap sarana dan prasarana tersebut menunjukkan bahwa hanya sebagian kecil sarana yang tidak tersedia di sekolah, yaitu tempat temuan barang hilang dan kantin kejujuran. Terdapat kekurangan dalam hal pengelolaan sarana dan prasarana, yaitu: pemanfaatan yang belum optimal dan pemeliharaan yang kurang. Sarana dan prasarana pendukung yang ada dapat dimanfaatkan sebagai wahana pembentukan karakter, misal fasilitas tempat cuci tangan dapat untuk menanamkan kebiasaan sehat mencuci tangan sebelum dan sesudah makan. Selain pengelolaan yang baik, sekolah juga perlu memperhatikan perawatan dan pemeliharaan sarana dan prasarana sekolah. Dalam hal ini, diperlukan keterlibatan semua warga sekolah, terutama siswa. Keterlibatan siswa secara 
Evaluasi Program Pendidikan Karakter...

aktif dalam pemanfaatan, perawatan, dan pemeliharaan sarana prasarana serta lingkungan sekolah akan menumbuhkan rasa memiliki dan tanggung jawab untuk lebih peduli terhadap lingkungan sekolahnya.

5) Orang tua/wali siswa dapat terlibat dalam kegiatan pembudayaan dan penanaman karakter melalui beberapa kegiatan. Orang tua/ wali murid secara aktif mengikuti kegiatan rutin atau bergilir yang dilaksanakan pihak sekolah dalam pertemuan- pertemuan antara orang tua/wali murid dengan wali kelas atau guru bidang studi. Orang tua/wali siswa yang dijadikan narasumber oleh evaluator adalah wali siswa kelas 5 dan 6. Rata-rata profesi wali siswa yang diwawancarai adalah guru dan wiraswasta. Dimana waktu mereka pun terbatas dan terbagi antara keluarga dan pekerjaannya. Wali siswa memiliki cara yang berbeda-beda dalam mendidik putra- putrinya. Akan tetapi, tujuannya sama yaitu agar putra putrinya memiliki karakter yang baik. Hasil wawancara dengan wali siswa, semua orang tua mendukung program pendidikan karakter yang diadakan di sekolah. Orang tua merasa terbantukan dengan adanya program ini, dengan pembiasaan dalam setiap kegiatan-kegiatan yang ada di sekolah, mempengaruhi sikap anak ketika di rumah.

6) Kurikulum, kesiapan kurikulum menjadi dasar yang baik bagi implementasi pendidikan karakter di sekolah. Idealnya, sekolah membuat peta nilai yang telah terpilih dari tahun pertama sampai tahun terakhir kemudian mengintegrasikannya ke dalam silabus dan RPP. Dengan demikian, dalam dokumen silabus dan RPP akan termuat nilai karakter secara spesifik lengkap dengan indikatornya. Berdasarkan hasil studi dokumentasi rencana pelaksanaan pembelajaran evaluator menemukan bahwa RPP di SD Islam Daarus Shofwah sudah mencakup empat kompetensi inti, yaitu KI1 kompetensi keagamaan, KI2 kompetensi sosial, KI3 kompetensi pengetahuan, dan KI4 kompetensi keterampilan. Evaluator juga melakukan obsevasi langsung di kelas ketika guru sedang melaksanakan KBM. Hasil pengamatan evaluator, tenaga pendidik SD Islam Daarus Shofwah menerapkan semua kompetensi inti disetiap materi pembelajaran. Dari hasil observasi tersebut dapat disimpulkan bahwa penerapan nilai-nilai karakter telah diterapkan dengan baik ketika kegiatan belajar mengajar oleh guru, hal itu dibuktikan dalam pembiasaan dalam keseharian di sekolah maupun di kelas, siswa mengikuti dan mengimplementasikan apa yang telah dipelajari dan diarahkan yang dilakukan oleh guru.

Ketiga komponen proses, evaluator membagi 3 poin terkait dengan proses pelaksanaan pendidikan karakter di SD Islam Daarus Shofwah, diantaranya adalah sebagai berikut:

1) Bentuk Kegiatan pelaksaan pendidikan karakter Shofwah terbagi kedalam dua bagian yaitu kegiatan Intrakulikuler, dan Ekstrakulikuler. Kegiatan rutin yang dilaksanakan sekolah SD Islam Daarus Shofwah bekerjasama dengan kegiatan kepesantrenan mulai dari bangun tidur hingga menjelang tidur kembali. Kegiatan Intrakuliker merupakan program utama sekolah dilaksanakan pada proses pembelajaran yang dilakukan oleh tenaga pendidik untuk mengembangkan potensi yang dimiliki peserta didik dan mendidik peserta didik. Hasil kegiatan intrakulikuler ini, berupa raport yang akan diberikan kepada siswa setiap akhir semester, raport tersebut sudah memuat seluruh 
kompetensi inti termasuk kompetensi keagamaan dan sosial yang berhubungan dengan pendidikan karakter. Kegiatan ekstrakulikuler yang selama ini diselenggarakan SD Islam Daarus Shofwah juga merupakan salah satu media yang yang potensial untuk pembinaan karakter dan peningkatan mutu akademik peserta didik. Melalui kegiatan peserta didik. Ekstrakulikuler yang ada di SD Islam Daarus Shofwah Bojonggede, Bogor adalah sebagai berikut: pramuka (ekskul wajib kelas 4, 5 dan 6), panahan, melukis dan mewarnai, kerajinan tangan(khusus perempuan), tapak suci, futsal (khusus laki-laki), hadhroh (khusus laki-laki), tilawah. Fungsi dari kegiatan ekskul ini ada dua yaitu pengembangan dan sosial. Pengembangan, yaitu fungsi kegiatan ekstra kurikuler untuk mengembangkan kemampuan dan kreativitas peserta didik sesuai dengan potensi, bakat dan minat mereka. Sosial, yaitu fungsi kegiatan ekstrakurikuler untuk mengembangkan kemampuan dan rasa tanggungjawab sosial peserta didik. Setiap guru ekstrakulikuler menerapkan nilai-nilai karakter pada setiap kegiatan ekstrakulikuler. laporan hasilnya kegiatan tersebut akan tertuang pada hasil laporan abelajar siswa yaitu raport.

2) Konsep pelaksaan pendidikan karakter, dari hasil pengamatan dan wawancara, terdapat beberapa konsep pelaksanaan pendidikan karakter di SD Islam Daarus Shofwah meliputi :

- Pertama,kegiatan rutin yang dilaksanakan sekolah meliputi upacara bendera pada hari senin, sahalat dhuha, shalat berjamaah, berdo'a sebelum dan setelah belajar, dan piket kelas, antri ketika makan siang, serta tentunya dalam proses belajar mengajar. Selain kegiatan rutin yang dilakukan siswa, terdapat juga kegiatan rutin yang dilakukan guru yaitu briefing pagi untuk guru, program piket guru.

- Kedua, kegiatan spontan meliputi kegiatan di luar program sekolah. kegiatan tersebut yaitu dengan mengikuti acara-acara nasional, memperingati hari PHBI, dan mengikuti lomba-lomba.

- Ketiga, kegiatan keteledanan, evaluator mengamati semua komponen sudah berusaha memodelkan diri sebagai komponen pendidik karakter, bagaimana bersikap di dalam maupun di luar kelas, dari segi kerapihan dan kesopanan dalam berpakaian, kedisiplinan guu, serta menaati tata tertib.

- Keempat, dari hasil pengamatan, kegiatan pengkondisian yang sudah dilakukan sekolah meliputikegiatan kebersihan, menyediakan tempat sampah yang cukup, sarana ibadah yang luas, serta kondisi toilet yang bersih.

3) Daya dukung dan hambatan pelaksanaan pendidikan karakter. Dari hasil wawancara dan pengamatan, terdapat beberapa daya dukung dan hambatanhambatan dalam pelaksanaan pendidikan karakter di SD Islam Daarus Shofwah adalah. Dari segi daya dukung, pertama sekolah telah menyediakan fasilitas atau sarana yang mendukung pelaksanaan pendidikan karakter. Hal ini dapat dibuktikan dengan adanya tempat sampah di setiap ruang kelas dan ruangan lainnya, sarana ibadah yang luas dan lain sebagainya. Kedua, dari segi implementasi pendidikan karakter dalam dokumentasi penilaian sikap siswa. Guru kelas (wali kelas) memiliki catatan tertulis dari hasil pengamatan terhadap sikap siswa, sehingga ada dasar untuk sekolah dapat membuat kesimpulan 
Evaluasi Program Pendidikan Karakter...

tentang pencapaian indikator nilai yang dimiliki oleh siswa. Dalam hal hambatan-hambatan yang dialami sekolah dalam pelaksanaan pendidikan karakter, pertama pelatihan guru mengenai pendidikan karakter dirasa masih kurang sehingga beberapa guru belum memaknai sepenuhnya mengenai pendidikan karakter di sekolah. kedua, kurangnya SDM yang berkualitas. ketiga, implementasi pendidikan masih lemah dalam dokumentasi penilaian sikap peserta didik. Ketiga, terdapat kesenjangan yang mungkin terjadi antara pendidikan yang diberikan sekolah dengan pendidikan di rumah.

Keempat komponen hasil atau product, dalam program pelaksanaan pendidikan karakter berupa nilai-nilai karakter yang tertanam dalam diri siswa, dan dibuktikan dengan hasil laporan persemester (raport). Nilai-nilai karakter dimuat berdasarkan pelaksanaan pendidikan karakter yang dilakukan secara terstruktur dan sistematis sesuai perencanaan yang telah dibuat. Nilai-nilai karakter dilaksanakan pada kegiatan belajar mengajar sesuai dengan rencana pelaksanaan pembelajaran (RPP) yang dibuat oleh masing-masing guru sesuai dengan kurikulum 2013. Dari hasil temuan dokumentasi, evalauator menemukan nilai-nilai karakter yang dimuat di SD Islam Daarus Shofwah terbagi menjadi dua yaitu sikap religius siswa dan sikap sosial siswa. Hal ini berdasarkan kompetensi inti 1(KI-1) dan kompetensi inti 2 (KI-2) yang ada dalam RPP. Dari hasil pengamatan dalam sikap religius siswa, semua siswa melaksanakan shalat 5 waktu secara berjama'ah di masjid untuk lakilaki dan shalat di musholla untuk perempuan dengan tertib. Dalam hal berdo'a, sebelum kegiatan belajar mengajar siswa berdo'a kemudian dilanjutkan dengan membaca asmaul husna. Namun, ada beberapa siswa yang harus diingatkan terlebih dahulu ketika membaca do'a. Dari hasil pengamatan dan wawancara dapat diambil kesimpulan bahwa nilai-nilai karakter peserta didik yang ada di SD Islam Daarus Shofwah berada pada kategori baik.

Selain nilai-nilai karakter yang diamati, komponen product dalam program pelaksanaan pendidikan karakter berupa laporan hasil belajar persemester (raport) dari kelas 4-6. Berdasarkan hasil studi dokumentasi ada dua laporan hasil belajar dan kegiatan peserta didik selama satu semesternya. Pertama laporan hasil akademik (raport) yang sesuai dengan kurikulum 2013. Rentang skor yang dinilai dari nilai karakter atau sikap religius dan sosial adalah $1-4$, dimana:

$1=$ Kurang sekali

$2=$ Kurang

$3=$ Baik

4= Baik sekali

Kedua adalah laporan kegiatan harian, akhlak dan perilaku siswa. Laporan kegiatan ini, sekolah bekerja sama dengan bagian keasramaan untuk melihat perkembangan karakter peserta didik dari mulai bangun tidur hingga menjelang tidur kembali. Dari hasil pengamatan, catatan anekdotal, tugas, laporan, dan sebagainya, guru memberikan kesimpulan atau pertimbangan tentang pencapaian suatu indikator atau bahkan suatu nilai. Kesimpulan atau pertimbangan itu dapat dinyatakan dalam pernyataan kualitatif sebagai berikut ini :

- BT : Belum Terlihat (apabila peserta didik belum memperlihatkan tandatandaawal perilaku yang dinyatakan dalam indikator). 
- MT: Mulai Terlihat (apabila peserta didik sudah mulai memperlihatkan adanyatanda-tanda awal perilaku yang dinyatakan dalam indikator tetapi belum konsisten).

- MB : Mulai Berkembang (apabila peserta didik sudah memperlihatkan berbagaitanda perilaku yang dinyatakan dalam indikator dan mulai konsisten).

- SM : Sudah Membudaya (apabila peserta didik terus menerus memperlihatkan perilaku yang dinyatakan dalam indikator secara konsisten).

Berikut persentase hasil studi siswa dari tahun akademik 2017/2018 dan 2018/2019. Data di ambil berdasarkan hasil dokumen dari wakil kepala sekolah bidang kurikulum SD Islam Daarus Shofwah Bojonggede, Bogor.

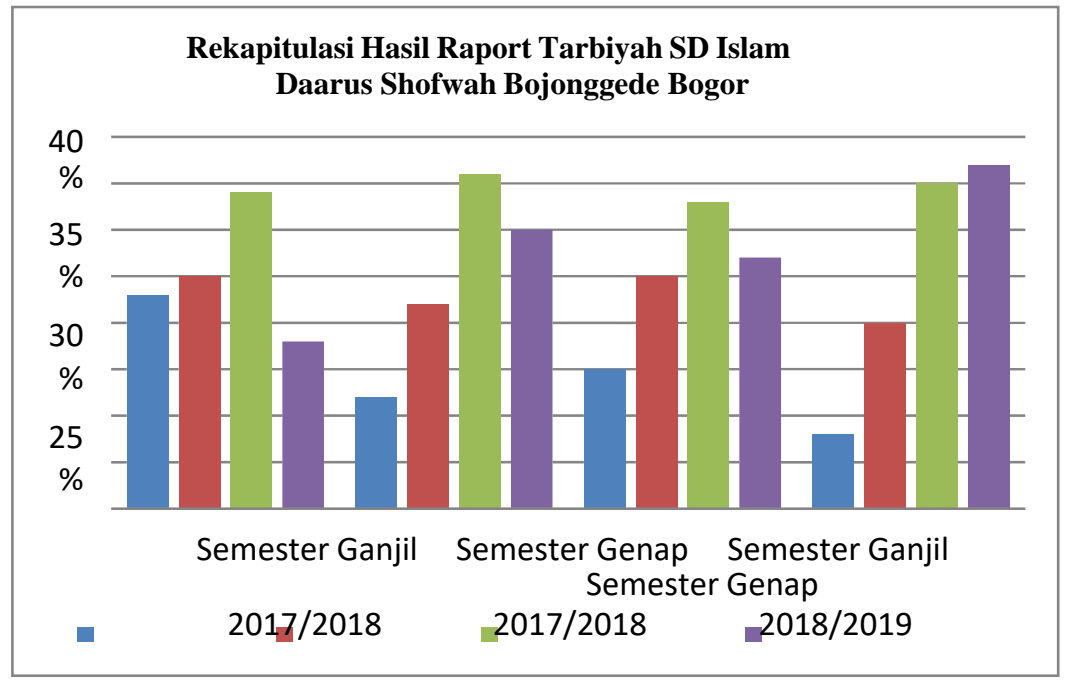

Grafik 1. Hasil Studi Tarbiyah SD Islam Daarus Shofwah

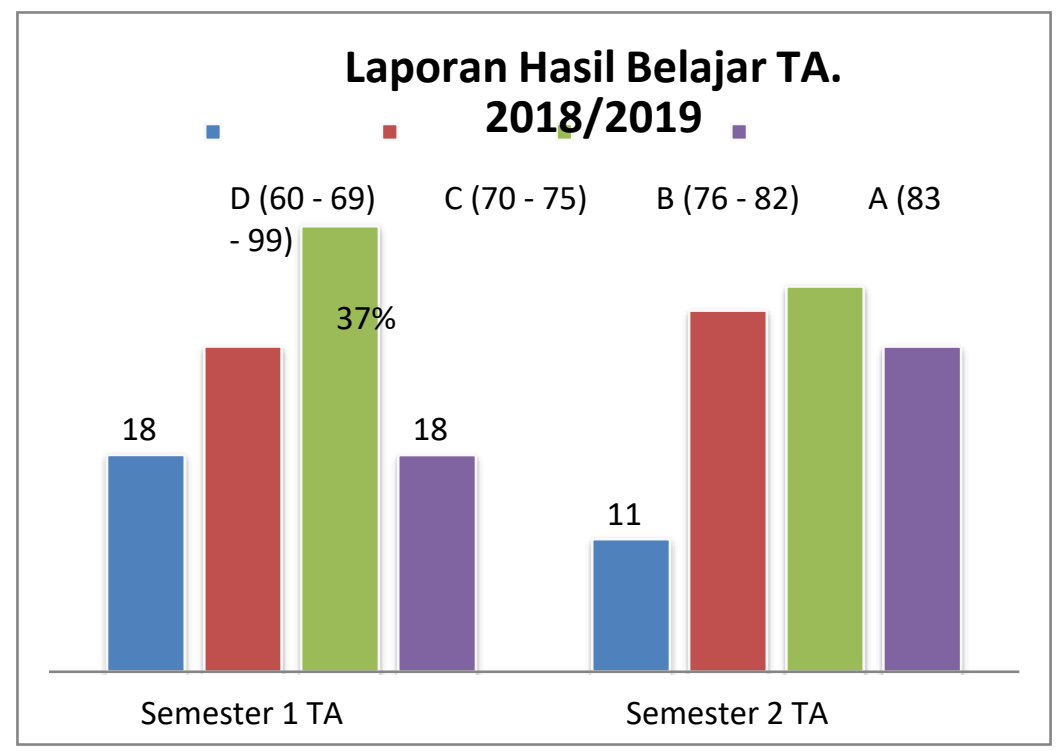

Grafik 2. Laporan Hasil Belajar Semester 1 dan 2 Tahun Akademik 2018/2019 
Dari hasil pengamatan dan studi dokumen melalui raport, dengan melihat raport tarbiyah semester 1 dan 2 tahun akademik 2017/2018 dan 2018/2019, dan raport hasil studi tahun akademik 2018/2019 dapat disimpulkan bahwa pendidikan karakter peserta didik mengalami perkembangan dan sudah mulai membudaya dalam diri peserta didik

\section{KESIMPULAN}

Berdasarkan analisis hasil evaluasi dari masing-masing tahapan, dapat disimpulkan bahwa program pendidikan karakter di SD Islam Daarus Shofwah Bojonggede Bogor mulai berkembang. Hal ini dapat dilihat dari empat aspek berikut :

1) Program pendidikan karakter di SD Islam Daarus Shofwah berdasarkan aspek konteks sebagian besar sudah terpenuhi dengan baik, dilihat dari program visi dan misi serta tujuannya jelas dan rinci.

2) Program pendidikan karakter di SD Islam Daarus Shofwah berdasarkan aspek inputberada pada kategori baik, dimana sarana dan prasarana sudah menunjang, namun dalam hal sumber daya manusia masih kurang, karena ada beberapa guru yang bukan dari program studi pendidikan.

3) Program pendidikan karakter di SD Islam Daarus Shofwah berdasarkan aspek proses berada pada kategori sangat baik hal ini didasarkan pada kegiatan-kegiatan yang ada di sekolah tersebut.

4) Program pendidikan karakter di SD Islam Daarus Shofwah berdasarkan aspek produk (Product) berada pada kategori baik, hal ini dilihat dari perbandingan raportkegiatan-kagiatan siswa mengalami peningkatan disemester berikutnya

\section{Implikasi}

Berdasarkan kesimpulan di atas, maka implikasinya adalah sebagai berikut :

1) Kurangnya persiapan dalam pelaksanaan program pendidikan karakter, khususnya pada persiapan sumberdaya manusia (guru). Implikasinya adalah, guru menjadi kurang memahami pendidikan karakter, sehingga tidak bisa dijadikan teladan oleh siswa.

2) Kurangnya kesadaran untuk mengaplikasikan dalam kehidupan sehari-hari. Implikasinya adalah masih ada peserta didik yang membuang sampah sembarangan, shalat berjam'ah masbuk, dan terlambat kegiatan belajar mengajar.

\section{Rekomendasi}

Berdasarkan hasil evaluasi, secara menyeluruh evaluator memberi masukan dan saran, semoga dapat bermanfaat bagi sekolah dalam pelaksanaan program pendidikan karakter dan untuk peneliti selanjutnya sebagai berikut :

1) Melakukan sosialisasi tentang program pendidikan karakter secara menyeluruh, baik kepada guru, maupun peserta didik.

2) Pendidik dan tenaga kependidikan tetap konsisten dan komitmen serta bertanggung jawab dalam memberikan nilai-nilai karakter kepada peserta didik dengan memberikan teladan kepada peserta didik, sehingga nilai-nilai karakter peserta didik dapat menjadi pembiasaan di kehidupan sehari-harinya. 


\section{DAFTAR PUSTAKA}

Acetylena, Sita. 2018. Pendidikan Karakter Ki Hadjar Dewantara. Malang : IntransPublishing

Amri, Sofan. 2011. Implementasi Pendidikan Karakter Dalam Pembelajarani. Jakarta:Prestasi Pustaka

Abdullah bin Muhammad bin Abdurrahman bin Ishaq al-Seikh. 2003 Tafsir Ibnu KatsirJilid 5. Jakarta: Pustaka Imam Syafi'I

Arikunto, Suharsimi. 2013. Dasar-Dasar Evaluasi Pendidikan.Jakarta : Bumi

Aksara Arikunto, Suharsimi dan Jabar, Cepi Safruddin Abdul. 2009.

Evaluasi Program Pendidikan:Pedoman Teoretis Praktis bagi Mahasiswa dan Praktisi Pendidikan. Jakarta: Bumi Aksara

Asy'ari, Hasyim. 2016. Pendidikan Karakter Khas Pesantren. Tangerang : Ts Mart Bungin, Burhan. 2017. Metodologi Penelitian Kualitatif Aktualisasi Metodologis ke Arah Ragam Varian Kontemporer. Depok : Rajawali Pers

Hamka, Abdul Ais. 2011. Pendidikan Karakter Berpusat Pada Hati, Akhlak MuliaPondasi Membangun Karakter Bangsa. Jakarta : Al-Mawardi

Hermino, Agustinus. 2014. Manajemen Kurikulum Berbasis Karakter. Bandung : Alfabeta

Komalasari, Kokom, Didin Saripudin. 2017. Pendidikan Karakter. Bandung : ReflikaAditama

Moleong, J. Lexy. 2013. Metodologi Penelitian Kualitatif. Bandung: PT. Remaja Rosdakarya.

Mulyasa. 2016. Manajemen Pendidikan Karakter. Jakarta: Bumi Aksara

Putro Widoyoko, S. Eko. 2017. Evaluasi Program Pembelajaran. Yogyakarta : PustakaPelajar

Rahman A. Ghani, Abd. 2014. Metodologi Penelitian Tindakan Sekolah. Jakarta: Rajawali Pers

Ramayulis. 2012. Ilmu Pendidkan Islam, Jakarta:Kalam Mulia

Samani, Muchlas, Hariyanto. 2016. Pendidikan Karakter Konsep dan Model.

Bandung : Rosda karya

Samsul Arifin, Bambang, H.A. Rusdiana. 2016. Manajemen Pendidikan

Karakter.

Bandung: Pustaka Setia

Saroni, Muhammad. 2019. Pendidikan Karakter Tanpa Kekerasan. Yogyakarta: Ar-Ruzz Media

Sugiyono. 2011. Metode Penelitian Kuantitatif Kualitatif dan R\&D. Banndung: Alfabeta

Sugiyono. 2014. Memahami Penelitian Kualitatif. Bandung: Alfabeta. 
Sukardi. 2015. Evaluasi Pendidikan Prinsip \& Operasionalnya. Jakarta : Bumi

AksaraSutarman. 2012. Buku Pengantar Teknologi Informasi. Jakarta: Bumi Aksara

Syah, Muhibbin. 2010. Psikologi Pendidikan. Bandung : Rosda

Tafs.ir, Ahmad. 2008. filsafat Pendidikan Islam. Bandung:Rosda Karya.

Tayibnapis, Farida Yusuf. 2008. Evaluasi Program dan Instrumen Evaluasi untuk Program Pendidikan dan Penelitian. Jakarta: Rineka Cipta

Peraturan Presiden No. 87 Pasal 2 Tahun 2017, Penguatan Pendidikan Karakter, (http://www.setkab.go.id/wp-content/upload/2017/09/Perpres No 87 tahun 2017, (Diakses 07 Juli 2019)

Efendi, F. 2016. Pemikiran Thomas Lickona tentang Pendidikan Karakter. Surabaya:UIN

Jaedun, Amat. 2010. Pelatihan Metode Penelitian Evaluasi Kebijakan dan EvaluasiProgram. Pendidikan.Jurnal Pendidikan. Yogyakarta: UNY 